\title{
Agrobacterium tumefaciens causing crown and stem gall disease of citrus propagation nursery in Iran
}

\author{
Aram Ganjeh ${ }^{1} \cdot$ Heshmatollah Rahimian ${ }^{1} \cdot$ Esmaeil Basavand $^{2}$ (I) \\ Received: 3 April 2020 / Accepted: 9 October 2020 / Published online: 19 October 2020 \\ (C) Società Italiana di Patologia Vegetale (S.I.Pa.V.) 2020
}

Keywords Agrobacterium tumefaciens $\cdot$ Citrus sinensis $\cdot$ Pathogenicity $\cdot$ Molecular diagnosis

In 2015, overgrowths on the budding sites of a few growing budlings of sweet orange cv. Navelina and Okitsu mandarin on Carrizo citrange (Poncirus trifoliate $\times$ C. sinensis) and on two seedlings of this rootstock species were encountered on a citrus propagation nursery in Sari county of Mazandaran province, Iran. From fresh galls, the predominant colonies similar to Agrobacterium on sucrose nutrient agar (SNA) and D1M media were isolated 2-3 days after incubation of plates at 25$28{ }^{\circ} \mathrm{C}$ (Basavand et al. 2020). All isolates (ten in total) were gram negative, aerobic, motile and catalase and oxidase positive. They grew on $2 \% \mathrm{NaCl}$ and at $35{ }^{\circ} \mathrm{C}$. Isolates hydrolyzed urea and Tween- 80 but not gelatin or starch. None were capable of producing a fluorescent pigment on King's B medium nor were able to produce indole or reduce nitrate. In pathogenicity test, the carrot (Daucus carota) discs in sterile Petri dishes and 3-months old citrange seedlings in greenhouse were inoculated by a bacterial suspension $c a .1 \times$ $10^{6} \mathrm{CFU} / \mathrm{ml}$ and were incubated at $26^{\circ} \mathrm{C}(10$ isolates with type strain A. tumefaciens ICMP 5856 T; 10 seedlings per isolate). Following 4 weeks after inoculation, callus symptoms on carrot discs and developing galls, $2 \mathrm{~mm}$ in diameter on citrange seedlings were observed. A sterile distilled water was utilized as control and the control plants remained symptomless. To fulfill Koch's postulates, re-isolation of inoculated tests isolates form citrange seedlings and carrot discs resulted on sucrose nutrient agar (SNA) and re-isolates were identified using conventional bacteriological methods. The $224 \mathrm{bp}$ fragments, typical for a fragment of the virD gene of

Esmaeil Basavand

e.basavand@vru.ac.ir

1 Department of Plant Pathology, Sari Agricultural Sciences and Natural Resources University, Sari, Iran

2 Department of Plant Pathology, Vali-e-Asr University of Rafsanjan, Rafsanjan, Iran the tumorigenic isolates and type strain A. tumefaciens (ICMP $5856 \mathrm{~T}$ ) was amplified in PCR using the primer pair virD2A/ virD2C (Bini et al. 2008). Further, part of the 16S rRNA gene of representative isolate (AR2) was amplified and sequenced (Weisburg et al. 1991). Thus, the nucleotide sequence (accession No. MT279042) shared 100\% identity to that of A. tumefaciens (strain cqsm- $\mathrm{fl}$ ) deposited in GenBank by BlastN analysis. To our knowledge, this is the first record of incidence of crown and stem gall caused by A. tumefaciens on citrus in Iran.

Acknowledgments The present study was supported by the Sari Agricultural Sciences and Natural Resources University, Iran.

\section{References}

Basavand E, Khodaygan P, Rahimian H, Solhizadeh A (2020) Bacterial leaf spot on Convolvulus arvensis caused by Pseudomonas sp. Indian Phytopathology 73:175-176

Bini F, Kuczmog A, Putnoky P, Otten L, Bazzi C, Burr TJ, Szegedi E (2008) Novel pathogen-specific primers for the detection of agrobacterium vitis and agrobacterium tumefaciens. Vitis 47:181189

Weisburg WG, Barns SM, Pelletier DA, Lane DJ (1991) 16S ribosomal DNA amplification for phylogenetic study. J Bacteriol 173:697-703

Publisher's note Springer Nature remains neutral with regard to jurisdictional claims in published maps and institutional affiliations. 